\title{
Stem cell treatment for patients with autoimmune disease by systemic infusion of culture-expanded autologous adipose tissue derived mesenchymal stem cells
}

Jeong Chan Ra ${ }^{1 *}$, Sung Keun Kang ${ }^{1}$, II Seob Shin ${ }^{1}$, Hyeong Geun Park', Sang Aun Joo', Jeong Geun Kim², Byeong-Cheol Kang ${ }^{3}$, Yong Soon Lee ${ }^{4}$, Ken Nakama ${ }^{5}$, Min Piao ${ }^{6}$, Bertram Sohl ${ }^{7}$ and Andras Kurtz ${ }^{8^{*}}$

\begin{abstract}
Prolonged life expectancy, life style and environmental changes have caused a changing disease pattern in developed countries towards an increase of degenerative and autoimmune diseases. Stem cells have become a promising tool for their treatment by promoting tissue repair and protection from immune-attack associated damage. Patient-derived autologous stem cells present a safe option for this treatment since these will not induce immune rejection and thus multiple treatments are possible without any risk for allogenic sensitization, which may arise from allogenic stem cell transplantations. Here we report the outcome of treatments with culture expanded human adipose-derived mesenchymal stem cells (hAdMSCs) of 10 patients with autoimmune associated tissue damage and exhausted therapeutic options, including autoimmune hearing loss, multiple sclerosis, polymyotitis, atopic dermatitis and rheumatoid arthritis. For treatment, we developed a standardized culture-expansion protocol for hAdMSCs from minimal amounts of fat tissue, providing sufficient number of cells for repetitive injections. High expansion efficiencies were routinely achieved from autoimmune patients and from elderly donors without measurable loss in safety profile, genetic stability, vitality and differentiation potency, migration and homing characteristics. Although the conclusions that can be drawn from the compassionate use treatments in terms of therapeutic efficacy are only preliminary, the data provide convincing evidence for safety and therapeutic properties of systemically administered AdMSC in human patients with no other treatment options. The authors believe that exvivo-expanded autologous AdMSCs provide a promising alternative for treating autoimmune diseases. Further clinical studies are needed that take into account the results obtained from case studies as those presented here.
\end{abstract}

Keywords: Autologous adipose mesenchymal stem cells, autoimmune diseases, systemic stem cell infusion

\section{Introduction}

In the $21^{\text {st }}$ century, live expectancy has rapidly progressed as has the number of previously uncommon diseases with no treatment. Stem cell based therapies are suggested to be able to repair and regenerate tissues in diseases associated with age, changed life style and environmental exposure, such as autoimmune disease and

\footnotetext{
*Correspondence: jcra@rnl.co.kr; Andreas.Kurtz@charite.de 'Stem Cell Research Center, RNL BIO, Seoul, 153-768, Republic of Korea ${ }^{8}$ Berlin-Brandenburg Center for Regenerative Therapies, Augustenburge Platz 1, 13353 Berlin, Germany and Seoul National University, College of Veterinary Medicine, Seoul, Korea

Full list of author information is available at the end of the article
}

stroke. In particular, mesenchymal stem cells (MSCs) have been applied to treat these diseases [1-3]. However, the lack of optimized culture protocols for achieving sufficient number of cells, safety issues concerning ex-vivoexpanded cells, the possible reduction in potency of stem cells derived from aged people and patients with autoimmune disease has put into question clinical applications of autologous stem cells in these patients.

In order to apply human autologous adipose tissue derived MSC (hAdMSC) in the clinical setting, we developed a standardized protocol to isolate and culture-expand AdMSC from minimal amounts of fat in vitro, achieving sufficient cell numbers for multiple

\section{(Ciomed Central}


therapeutic inventions [4]. Expanded AdMSCs maintained the potency for effective differentiation independently of donor age and disease status [5]. The confirmed genetic stability and in vivo safety of ex-vivoexpanded hAdMSCs in animal models and patients [4] indicate that AdMSCs from older persons are applicable for autologous therapy and are comparable to those derived from young donors [5]. Furthermore, we investigated the migration ability of hAdMSCs and their in vivo homing in animal model after systemic infusion.

MSC include a number of stem cells with an inherent ability for self-renewal and differentiation potential for mesodermal and other embryonic lineages, including adipocytes, osteocytes, chondrocytes, hepatocytes, neurons, muscle cells and epithelial cells [6-8], depending on the surrounding microenvironment. A large body of evidence demonstrated that MSC commonly have immunomodulatory and anti-inflammatory properties [9-12]. While the differentiation properties of MSC seem to dependent on microenvironmental clues in vivo, the immunomodulatory effects appear to be rather intrinsic and thus present an attractive basis for the therapy of autoimmune and inflammatory diseases by systemic infusion. Moreover, intrinsic properties of MSC demonstrated secretion of various factors, modulation of the local environment and activation of endogenous progenitor cells $[13,14]$. Hence, MSC therapy evoked therapeutic promises for graft-versus-host disease (GVHD), systemic lupus erythematosus (SLE), rheumatoid arthritis (RA), multiple sclerosis (MS), diabetes, myocardial infarction, thyroditis and different types of neurological disorders, among others [15-23].

Various routes of administration of MSCs, including intravenous (i.v.) [24], intraarterial [25] or intracerebral [26] were reported for stem cell application. Of these routes, i.v. is a convenient strategy to deliver cells and therapeutic effects to the injury site. Intravenously injected MSC may be transiently trapped in the lungs, sequestered in the spleen, and are predominantly eliminated by kidneys [27]. Initial accumulation of MSC in the lungs may induce secretion of secondary anti inflammatory effectors [28].The recent demonstration of in vivo homing properties of bone marrow derived MSCs and AdMSCs has further stimulated i.v. application of MSC for therapy [29]. In this review, we describe several cases of autologous AdMSCs application in autoimmune conditions, including autoimmune hearing loss, MS, polymyotitis (PM), atopic dermatitis (AD) and RA. We suggest that multiple infusions of AdMSC may establish immune homeostasis over long periods of time.

\section{Phenotype and differentiation potentials of MSCs}

Minimal criteria have been proposed to define MSCs by the Mesenchymal and Tissue Stem Cell Committee of the International Society for Cellular Therapy. These are: 1) plastic adherence ability; 2) lack of hematopoietic markers, such as CD45, CD34, CD14, CD11b, CD79 $\alpha$, CD 19, or HLA-DR; 3) tripotential mesodermal differentiation potency into osteoblasts, chondrocytes, and adipocytes; and 4) immunomodulatory capability [30]. In addition to their mesodermal differentiation capability, MSCs were also shown to differentiate in vitro into the ectodermal lineage such as neurons, but also into the endodermal lineage such as myocytes and hepatocytes [7,31]. The conditions for differentiation of engrafted MSCs in vivo might be more complex and regulated by microenvironmental cluses of local tissues. For example, MSCs engrafted into heart could differentiate into cardiomyocytes, smooth muscle cells, and vascular endothelial cells [32-34]. In addition, through a series of signals from local tissue, engrafted MSCs can be induced to secrete diverse cytokines that posses trophic and immunomodulatory functions and subsequently contribute to tissue repair and regeneration [11].

\section{Sources of MSCs}

MSC were first isolated as fibroblast colony-forming units (CFU-Fs) or marrow stromal cells from bone marrow (BMMSC) by Friedenstein and colleagues [35]. Their most common name is based on their property of differentiate into a variety of mesodermal tissues including bone, cartilage and fat. MSCs were found in various organs and tissues, including fat, periosteum, synovial membrane, synovial fluid, muscle, dermis, deciduous teeth, pericytes, trabecular bone, infrapatellar fat pad, articular cartilage, umbilical cord and cord blood [36,37], and placenta [38].

BMMSCs have first been applied for therapy $[39,40]$. However, aspirating BM from the patient is an invasive procedure that yields only low numbers of cells (about $1-10$ per $1 \times 10^{5}$ or $0.0001-0.01 \%$ of all BM nucleated cells), requiring high expansion rates [41]. Furthermore, the therapeutic potential of BMMSCs may be diminished with increasing donor age and is associated with declining differentiation capacity and reduced vitality in vitro [42]. In any case, for autologous transplantation, expanded BMMSCs and AdMSCs have safely been applied in numerous human studies $[4,39,40]$.

\section{Adipose mesenchymal stem cells}

Adipose tissue is an attractive source of MSCs for autologous stem cell therapy, because adipose tissue is easily obtainable in sufficient quantities using a minimally invasive procedure $[23,43]$. In addition, adipose tissues contain more MSCs than BM (about 100, 000 MSCs per gram of fat) [44]. Moreover, differentiation and immunomodulatory potencies of AdMSCs are equivalent to those of BMMSCs [23]. 
The efficacy of AdMSCs in treating various diseases has been reported in vivo [45]. Local or systemic administration of AdMSCs was reported to have repair capacity in myocardial infarction [19] liver injury [24], hypoxia-ischemia-induced brain damage [46], allergic rhinitis [47] and muscular dystrophy [48]. Furthermore, AdMSCs are immune regulatory and potentially suitable to treat immune-related diseases including GVHD [15], MS [16], rheumatic disease [17,18] and thyroditis [20].

Establishment of standard culture-expansion procedure of hAdMSCs for clinical applications

Due to the small number of MSC in tissues, ex vivo expansion is required to generate the cell quantities required to achieve therapeutic results with MSCs through systemic delivery. In case of BMMSCs, however, long-term culture alters the quality of MSCs, including morphological changes, attenuated expression of specific surface markers, reduced proliferative capacity, differentiation potential [49-52], and trophic activity [53].

To produce sufficient numbers of hAdMSCs for stem cell therapy, optimized culture conditions were developed [4], which allow proliferation of hAdMSC from minimal amounts of fat since large amounts of fat are rarely obtainable from patients suffering from incurable diseases. Usage of a special cannular maximizes survival rate of stem cells in fat tissues and a 3 times higher rate of subsequent early stem cell attachment when compared to other devices. The developed cell collection, cultivation and expansion protocol requires less than 5 $\mathrm{g}$ fat to obtain more than $10^{9}$ cells (after 3 passages). To improve proliferation and differentiation of AdMSC, we tested more than 15 commercially available culture media and eventually developed the hAdMSC culture media, named as RCME (MSC attachment media) and RKCM (MSC proliferation media) [4]. These media provide high viability, shortened doubling times and maintained morphology and improved potency.

The characteristics, stability, toxicity, and tumorigenicity of the culture-expanded hAdMSCs were determined in animals and in human studies [4]. With regard to the safety of culture-expanded stem cells in vitro, genetically stability and consistency on the morphological, immunophenotypic, and differentiation characteristics, as well as toxicity and tumorigenicity need to be verified. We demonstrated that cultured hAdMSCs showed the typical immunophenotype and differentiation capability of MSCs [4]; cells expressed MSC markers CD90, CD105, CD44 and CD29, but did not express hematopoietic or endothelial markers (CD31, CD34 and CD45) and differentiated to adipogenic, osteogenic, neurogenic, myogeneic and chondrogeneic lineages in vitro. Cultureexpanded hAdMSCs were genetically stable for at least 12 passages as determined by karyotype and single nucleotide polymorphism (SNP) assays.
Cells suspended in physiological saline maintained their MSC properties, viability and potency at cold storage conditions $\left(2\right.$ to $8^{\circ} \mathrm{C}$ ) for at least $72 \mathrm{~h}$, a critical time period for shipping stem cells into the clinic. However, we noticed that physical vibration during shipment might negatively impact cell viability. No evidence of bacterial, fungal, or mycoplasma contamination was observed in cells tested before shipping and cell viability evaluated by trypan blue exclusion was > 95\% prior to cell transplantation.

\section{In vivo safety of expanded hAdMSCs}

To test the toxicity of hAdMSCs, different cell doses were intravenously injected into immunodeficient severe combined immunodeficiency (SCID) mice, and mice were observed for 13 weeks. Even at the highest cell dose $(2.5 \times$ $10^{8}$ cells $/ \mathrm{kg}$ body weight), mice showed no sign of discomfort. Although the safety of i.v. injection of culture expanded autologous and allogenic MSCs has been confirmed in patients [54] in numerous human clinical studies including osteogenesis imperfect [55], metachromatic leukodystrophy [56], acute myocardial infarction [57] and GVHD [58], there were some reports presenting that MSCs can induce sarcoma [59] or facilitate the growth of tumors [60]. In order to test tumorigenicity of hAdMSCs, we performed a tumorigenicity test in Balb/c-nude mice for 26 weeks. Even at the highest cell dose $\left(2 \times 10^{8} \mathrm{MSCs} /\right.$ $\mathrm{kg}$, subcutaneous injection), no evidence of tumor development was found. The safety of hAdMSCs was further investigated in a phase I human clinical trial, with no serious adverse event after i.v. administration of $4 \times 10^{8}$ hAdMSCs within an observation period of 12 weeks [4]. The minor adverse events found are common to spinal cord injury patients and disappeared spontaneously or were alleviated with medication. One idiopathic case of asymptomatic hyperthyroidism that did not require medical treatment remained sustained during follow-up. Based on these studies, we conclude that the systemic administration of hAdMSCs is safe and does not induce tumor development. In line with these data, Vilalta et al. [61] reported that hAdMSCs implanted in mice tended to maintain a steady state, and no detectable chromosomal abnormalities or tumors formed during the 8 months of residence in the host's tissues. Notably, the development of sarcoma in the study of Tolar et al was due to cytogenetically abnormal culture-expanded MSCs [59]. In addition, Izadpanah et al. [62] demonstrated that long-term cultivation of MSC beyond passage 20 may result in their transformation to malignant cells. These results indicate that it is essential to control genetic stability of cultureexpanded cells.

\section{Comparison of neural cell differentiation of hAdMSC derived from young and old donors}

Because many diseases that are candidates for stem cells therapy are age-associated degenerative diseases, stem 
cells obtained from the elderly for autologous use should possess potency in order to have therapeutic effects. In terms of BMMSCs, there have been controversial results regarding the effects of aging. Using human BMMSCs from juveniles and adults seeded onto three-dimensional scaffolds, Mendes et al. [63] have demonstrated that actual bone formation decreased significantly as patient age increased. Huibregtse et al. [64] demonstrated that overall reduction in colony-forming efficiency was observed in rabbit BMMSCs derived from older animals. Bergman et al. [65] demonstrated that differences in basal proliferation rates were observed between young and old BMMSCs isolated from mice, while production of early markers of osteoblastic differentiation in vitro were equivalent. Stenderup et al. [42] have shown that human BMMSC isolated from older donors have a decreased lifespan and rate of population doubling, while both BMMSCs formed similar amounts of bone both in vitro and in vivo [51].

Adipose derived MSC seem not to undergo the same senescence pattern as BMMSC [66,67]. When hAdMSC were derived from elderly (mean 71.4 years) and young donors (mean 36.4 years), cells from both age groups showed similar proliferation, osteogenic differentiation and senescence marker patterns, while BMMSC from the same cohorts showed reduced proliferation, decreased differentiation and increased senescence [66]. In concordance with these findings are data from murine AdMSC derived from senile osteoporotic SAMP6 mice, which showed maintenance of telomere length, telomerase activity and osteogenic differentiation [67]. In order to determine the potency of hAdMSCs isolated from donors aged thirty, forty and fifty, their proliferation and differentiation potential to neural cells was investigated [5]. It was demonstrated that cell number, viability, morphology and neural differentiation potential were not different between hAdMSC of different age and passage. The results suggest that autologous adipose derived stem cells from aged people may be applied for stem cell therapy of age-dependent neural disease with the same stem cell quality and ability as stem cells derived from younger patients.

\section{Distribution, migration and homing potential of transplanted MSCs after intravenous injection Distribution of MSCs after i.v. injection}

After i.v. delivery, MSCs are generally found at low or very low frequencies in most target organs, as shown by histology, polymerase chain reaction or by immunohistochemistry [68-70]. Deak et al. [71] performed systematic kinetic assessments in non-injury models using enhanced green fluorescent protein transfected murine MSCs. They demonstrated that $24 \mathrm{hr}$ after MSC application, the most frequently positive organs were lungs, liver, kidney, skin, and gut among investigated tissues. In baboons, Devine et al. [69] demonstrated that high concentration of transplant specific DNA was observed in gastrointestinal tissues. They also showed that kidney, lung, liver, thymus, and skin have relatively high amounts of DNA equivalents. Based on their studies, levels of engraftment in these tissues were estimated, ranging from 0.1 to $2.7 \%$, with similar results with autologous and allogeneic cells [69]. After systemic administration, Lee et al. [28] found $80 \%$ of the infused MSCs in the lungs of mice $15 \mathrm{~min}$ after infusion, whereas after 4 days the specific signal for the presence of human MSCs decreased to $0.01 \%$. Of importance, clinical studies with systemically delivered human MSCs did not induce significant intolerance symptoms from the pulmonary or circulatory systems, while murine MSCs displayed a somewhat different behavior. Deak et al. [72] have demonstrated in a C57BL/6 syngenic murine MSCs transfusion model, that in contrast to human MSCs, murine MSCs home to lungs and might clog in the lungs.

Migration and homing potential of MSCs after i.v. injection A number of in vivo studies have shown that systemically infused MSCs could migrate to injured, inflamed tissues and exert therapeutic effects [73,74]. BMMSCs intravenously delivered to rats following myocardial infarction localize in the infarct region and improve ventricular function, while MSCs delivered to non-infarcted rats localize to the BM [75]. Localized abdomen irradiation significantly enhances MSC homing specifically to radiation-injured tissues in mice [76]. A recent study demonstrated the homing properties of i.v. administered hAdMSCs to cell-damaged areas in an allergic rhinitis animal model [47]. The relative organ distribution of fluorescence-labeled hAdMSCs was assessed by us in brain, spinal cord, spleen, thymus, kidney, liver, lung, and heart after i.v. injection in spinal cord injury rats by fluorescence microscopy and human specific Alu PCR. In the injured region of spinal cord, a relatively high percentage of AdMSCs (13\%) was found, while most cells remained in spleen $(40 \%)$ and thymus (21\%) [data not shown].

Numerous studies showed the involvement of chemokines or growth factors in MSCs trafficking to the injury region. The interactions of stromal cell-derived factor$1 \alpha$ (SDF-1 $\alpha$ )- and C-X-C chemokine receptor type 4 (CXCR4) mediated the trafficking of transplanted BMMSCs in a rat model of left hypoglossal nerve injury. In addition, BMMSCs were attracted by chemokines that are presented in the supernatants of primary cultures of human pancreatic islets culture in vitro and in vivo [77]. When we compared soluble factors by in vitro migration assay, platelet derived growth factor (PDGF)$\mathrm{AB}$ and transforming growth factor- $\beta 1$ (TGF- $\beta 1$ ) were 
most potent for migration activity of hAdMSCs [78]. hAdMSCs pre-stimulated with tumor necrosis factor (TNF- $\alpha$ ) showed the highest migration activity. When analyzed by flow cytometry and reverse transcriptasepolymerase chain reaction, hAdMSC expressed $\mathrm{C}-\mathrm{C}$ chemokine receptor type 1 (CCR1), CCR7, C-X-C chemokine receptor type 4 (CXCR4), CXCR5, CXCR6, EGFR (EGF receptor), FGFR1 (FGF receptor 1), TGFBR2 (TGF receptor 2), TNFRSF1A (TNF receptor 1), PDGFRA (PDGF receptor A) and PDGFRB (PDGF receptor B) at protein and mRNA levels. This study indicates that the migration of hAdMSCs is controlled by various growth factors or chemokines. Hence, modulating the homing capacity of hAdMSCs in vivo could stimulate its migration into injured sites after i.v. administration, and thereby improve their therapeutic potential.

\section{Immunomodulation and anti-inflammatory effects by MSCs}

Several characteristics may play a role for the immune regulatory capability and anti-inflammatory effects of MSCs: 1) MSCs have low immunogenicity due to low expression levels of major histocompatibility complex-I (MHC-I) and no expression of MHC-II molecules and costimulatory molecules including B7-1 (CD80), B7-2 (CD86), or CD40 [79], (2) MSCs secrete soluble factors such as interleukin (IL)-6 and macrophage-colony stimulating factor [80] and suppress the activation and proliferation of $\mathrm{T}$ and $\mathrm{B}$ lymphocytes, and interfere with differentiation, maturation and function of dendritic cells, (3) MSC release anti-inflammatory and anti-apoptotic molecules and hence may protect damaged tissues $[79,81]$.

Due to these properties, MSC transplantation has been used for the treatment of GVHD, and several autoimmune diseases, including autoimmune thyroditis [20], RA $[17,18]$ and MS [16] and implicated for allogeneic stem cell transplantation. Systemic infusion of AdMSCs controlled lethal GVHD in mice transplanted with haploidentical hematopoietic stem cell grafts when the MSCs were injected early after transplantation [15] although ongoing clinical studies with allogeneic BMMSC were not successful. Therapeutic efficacy of BMMSCs was reported in the animal model of MS [16]. In this experimental autoimmune encephalomyelitis (EAE) model, i.v. infusion of MSCs decreased clinical symptoms when MSCs were injected before or at the onset of the disease. In an experimental collageninduced arthritis (CIA) study, a single intraperitoneal injection of BMMSCs prevented the occurrence of severe arthritis, and was associated with a decrease in serum levels of pro-inflammatory cytokines [18]. Human AdMSCs have been demonstrated to ameliorate experimental autoimmune thyroiditis via down-regulation of
Th1 cytokines [20]. Systemic infusion of hAdMSCs prevented lymphocyte infiltration to thyroid glands, decreased the production of pro-inflammatory cytokines and improved Th1/Th2 balance [20]. MSCs suppressed $\mathrm{T}$-cell proliferation and cytokine production in response to alloantigen and nonspecific antigen, and prolong skin graft survival in vivo [82]. In addition, MSCs inhibit function of B cells [83], natural killer cells [84] and dendritic cells [85]. The immunomodulatory function of MSC was mediated both by soluble factors [86], and by direct cell to cell interactions [87].

Whether MSC derived from patients with autoimmune diseases will have therapeutic functions after autologous transplantation in a clinical situation is controversial and has not been addressed clinically [88]. Papadaki et al. [89] showed that while BMMSCs isolated from RA patients were found to be impaired in their ability to support hematopoiesis, BMMSCs isolated from MS patients displayed normal ability $[89,90]$. Other data demonstrated that BMMSCs derived from patients with RA, MS, autoimmune SLE, systemic sclerosis (SSc) and Sjogren's syndrome retained their immunomodulatory capabilities in vitro [91,92].

\section{Clinical application of MSCs in autoimmune diseases}

Given their confirmed in vivo safety and the rationale that MSCs possess immunomodulatory and anti-inflammatory properties, compassionate-use treatments for autoimmune diseases were initiated in patients after other treatment options were exhausted. All patients provided informed consent to the treatment. Here, we describe treatment of AdMSCs in autoimmune hearing loss (AIED), MS, PM, AD and RA. Details on the patients disease and treatment histories, disease status and treatments are provided in Table 1 and Additional File 1; Case Reports, Table S1 and Figure S1. Additional clinical scores for AD before and after treatment are shown in Table 2. Patient analysis was based mostly on clinical parameters. In some cases, immunological and blood status parameters were also measured (cases 3, 4, $5,8,9,10)$; all cases showed decrease in inflammatory responses and eosinophil counts.

For all treatments, $5 \mathrm{~g}$ of fat tissues were collected by liposuction, transferred immediately to the GMP facility and Stem Cell Research Center of RNL BIO and culture-expanded for 3 passages using the standard protocol to obtain AdMSCs [4]. The patients received between 1 and 6 i.v. infusions of 200 million AdMSCs suspended in physiological saline (each 100 million cells $/ 100 \mathrm{ml}$ ) in different intervals (see Table 1 and Additional File 1; Case Reports). Two patients received additional intrathecal (MS-patient) and intrarticular (RA-patient) injections of cells (Table 1 and Additional File 1; Case Reports and Table S1). 
Table 1 Summary of hAdMSC treatments of 10 patients with different autoimmune-associated diseases.

\begin{tabular}{|c|c|c|c|c|c|c|}
\hline Case & Age/Sex & $\begin{array}{l}\text { Injections and } \\
\text { cell numbers }\end{array}$ & $\begin{array}{l}\text { Total cell } \\
\text { number } \\
\text { received }\end{array}$ & Clinical status at presentation & Clinical status after treatment & $\begin{array}{l}\text { Observation } \\
\text { time } \\
\text { (months) }\end{array}$ \\
\hline \multicolumn{7}{|c|}{$\begin{array}{l}\text { Autoimmune inner ear disease (AIED) } \\
\text { AIED [93,94]is a progressive, bilateral yet asymmetric, sensorineural hearing loss. Patients have higher frequencies of interferon (IFN)-c- } \\
\text { producing T cells and higher serum antibody titres compared with healthy controls and patients with noise- and/or age-related hearing loss } \\
\text { [95]. The mainstay treatment for AIED are anti-inflammatory drugs, particularly corticosteroids [96,97]. However, some patients are refractory } \\
\text { to steroid treatment. Thus, alternative treatment is needed for these patients. Efficacy of hAdMSCs on experimental autoimmune hearing loss } \\
\text { (EAHL) was shown in mice [98]. Mice were immunized with } \beta \text {-tubulin to develop EAHL and treated with i.v. injection of hAdMSCs (once a } \\
\text { week for } 6 \text { consecutive weeks) resulting in improved hearing, hair cell stabilization, reduced proliferation of antigen-specific Th1/Th17 cells } \\
\text { and induced anti-inflammatory cytokine IL-10 in splenocytes, induction of antigen-specific CD4(+) CD25(+) Foxp3(+) regulatory T-cells with the } \\
\text { capacity to suppress autoantigen-specific cytotoxic T-cell responses. }\end{array}$} \\
\hline 1 & $19 / \mathrm{F}$ & $\begin{array}{l}3 \times \text { each } 2 \times 10^{8} \\
\text { (i.v.) }\end{array}$ & $6 \times 10^{8}$ & $\begin{array}{l}\text { Severe progressing hearing loss for } 3 \\
\text { years (no in left ear, severe in right ear) }\end{array}$ & $\begin{array}{l}\text { Normal hearing in right ear, } \\
\text { moderate hearing in left ear }\end{array}$ & 11 \\
\hline
\end{tabular}

\section{Multiple Sclerosis (MS)}

MS is a multifocal inflammatory disease of the central nervous system, which mainly affects young women between ages twenty and forty years and causes paralysis of the limbs, sensation, visual and sphincter problems. The disease is clinically evident with relapses of neurological disability due to damage of myelin occurs (plaques of sclerosis). The disease enters a progressive phase due to damage of the axons and irreversible neurodegeneration. Existing immunotherapies downregulate the autoimmune anti-myelin reactivity and reduced the rate of relapses (e.g. INF- $\beta$, glatiramer acetate and mitoxantrone) but progression of disability and myelin regeneration is not possible [99,100]. In the chronic EAE animal model [101], BMMSCS and AdMSCs were shown to restore neuronal activity and produce new neurons $[102,103]$. We demonstrated previously that hAdMSCs ameliorates the symptoms in EAE in a dose-and time-dependent manner, and these effects can be mediated in part by the production of anti-inflammatory cytokines [104].

\begin{tabular}{lllll}
\hline $246 / F$ & $5 \times$ each $1 \times 10^{8}$ & $1.03 \times 10^{9}$ & EDSS $^{*} 8$ & EDSS 7 \\
& & & \\
& (i.v.) \\
& $3 \times$ each $1 \times 10^{7}$ & & \\
& (intrathecal) & & & \\
&
\end{tabular}

\section{Polymyositis}

PM is a type of chronic inflammatory myopathy with unknown etiology associated with invasion of white blood cells in muscle tissue. PM is related to dermatomyositis and inclusion body myositis. Clinical signs include pain with proximal muscle weakness and loss of muscle mass, particularly in the shoulder and pelvic girdle. Despite the uncertainty in the exact cause of PM, autoimmune, viral, infectious or genetic factors have been suggested. The estimated annual incidence rate is around 5-10 cases/1,000,000 in the United States; it increases with age, with the highest rates seen in the 35-44 and 55-64 years. Women are two times more likely to suffer from PM than men. Corticosteroids and immunosuppressant agents are the mainstay of treatment, with a significant percentage of non-responders and clinical relapses [105]. Hematopoietic stem cell transplantation is performed in patients with refractory PM with satisfactory clinical efficacy [106], but the condition regimen for the procedure has many side effects. Allogeneic MSCs from bone marrow and umbilical cord were transplanted in 10 patients with drug-resistant PM [107]. Although none of the patients stopped immunosuppressive therapy for more than 1-year's follow-up and there was no cure, MSCS treatment may prove to be a useful adjunctive treatment in patients whose disease is poorly controlled with immunosuppressive agents.

\begin{tabular}{|c|c|c|c|c|c|}
\hline 3 & $35 / F$ & $\begin{array}{l}4 \times \text { each } 5 \times 10^{8} \\
\text { (i.v.) }\end{array}$ & $2 \times 10^{9}$ & $\begin{array}{l}\text { inability to walk slope and to stand up } \\
\text { by herself }\end{array}$ & $\begin{array}{l}\text { Able to step up stairs }(<10 \mathrm{~cm}) \text { and } \\
\text { walk gentle slope holding handrail }\end{array}$ \\
\hline
\end{tabular}

\section{Atopic Dermatitis}

$A D$ is a common, chronic and refractory skin disease manifesting as eczema and pruritus with repeated exacerbations and regressions and unknown pathogenesis [108]. The incidence of AD in adults has increased worldwide over the past decade [109]. Current management aims to relieve frequency of dermal inflammation and prevent its flare-up using topical corticosteroids and tacrolimus [109,110]. Although these treatments might control the symptoms, relapse is frequent and extensive and prolonged use of corticosteroid carries risk of side-effects, including skin atrophy and there are many $A D$ patients with corticosteroid phobia [111]. Despite the immunomodulating effect of MSC, there is no previous record of stem cell treatment of AD.

\begin{tabular}{|c|c|c|c|c|c|c|}
\hline 4 & $27 / F$ & $\begin{array}{l}3 x \text { each } 2 \times 10^{8} \\
\text { (i.v.) }\end{array}$ & $6 \times 10^{8}$ & SCORAD index 93.1 & SCORAD* index 61.1 & 5.5 \\
\hline 5 & $33 / \mathrm{M}$ & $\begin{array}{l}3 \times \text { each } 2 \times 10^{8} \\
\text { (i.v.) }\end{array}$ & $6 \times 10^{8}$ & SCORAD index 57.0 & SCORAD index 35.5 & 4.5 \\
\hline 6 & $27 / F$ & $\begin{array}{l}5 x \text { each } 2 \times 10^{8} \\
\text { (i.v.) }\end{array}$ & $1 \times 10^{9}$ & SCORAD index 33.4 & SCORAD index 16.4 & 3.5 \\
\hline 7 & $26 / F$ & $\begin{array}{l}3 \times \text { each } 2 \times 10^{8} \\
\text { (i.v.) }\end{array}$ & $6 \times 10^{8}$ & SCORAD index 39.1 & SCORAD index 13.3 & 2 \\
\hline
\end{tabular}

\section{Rheumatoid Arthritis}

$R A$ is a T-cell-mediated systemic autoimmune disease caused by loss of immunologic self tolerance and characterized by synovium inflammation and articular destruction. MSCS were reported to reduce inflammatory and T cell responses and induce antigen specific regulatory T cells in vitro in rheumatoid arthritis [112]. Systemic infusion of hAdMSCs significantly reduced the incidence and severity of experimental arthritis induced by CIA in vivo [113], which was mediated by down-regulating Th1-driven autoimmune and inflammatory responses and induction of interleukin-10 in lymph nodes and joints. Human AdMSCS also induced de novo generation of antigen-specific CD4+CD25+FoxP3+ Treg cells. The best therapeutic benefits were seen when the stem cell treatments were performed prior to onset and by systemic rather than local application. Recently, the therapeutic effects of systemic infusion human umbilical cord (UC)-MSCS were also verified in the collagen-induced arthritis model [114]with effects similar to those of hAdMSCS.

$850 / F \quad 2 \times$ each $3 \times 10^{8} 6 \times 10^{8} \quad *^{* *}$ VAS score: 10 KWOMAC score: $73 \quad$ VAS score:2-3 KWOMAC score: 28


Table 1 Summary of hAdMSC treatments of 10 patients with different autoimmune-associated diseases. (Continued)

\begin{tabular}{|c|c|c|c|c|c|c|}
\hline 9 & $51 / F$ & $\begin{array}{l}\text { Once } 2 \times 10^{8} \\
\text { (i.v.) }+1 \times 10^{8} \\
\text { (intrarticular) } \\
\text { Once } 3.5 \times 10^{8} \\
\text { (i.v.) }+1.5 \times 10^{8} \\
\text { (intrarticular)) }\end{array}$ & $8 \times 10^{8}$ & $\begin{array}{l}\text { Inability to stand up, crutches for } \\
\text { walking }\end{array}$ & Ability to stand up, off steroids & 3 \\
\hline 10 & $67 / M$ & $\begin{array}{l}4 x \text { each } 2 \times 10^{8} \\
\text { (i.v.) }\end{array}$ & $8 \times 10^{8}$ & Inability to walk & Normal walking, off steroids & 13 \\
\hline
\end{tabular}

Detailed clinical case reports are provided in the Additional File 1 Case Reports. Multiple sclerosis: *EDS is expanded disability status scale. Atopic dermatitis: The outcome was evaluated by the area of skin lesions, **SCORAD (SCORing Atopic Dermatitis) index [115,116] and CBC count. The changes of SCORAD index of each patient before and after AdMSCs treatment are summarized in table 1. Rheumatoid arthritis: ***VAS (Visual Analogue Scale) KWOMAC (Korean Western Ontario McMaster). Further information on patient profile and treatment for AIED are summarized in Additional File 1 Figure S1.

Table 2 SCORing results of AD patients.

\begin{tabular}{|c|c|c|c|c|c|c|c|c|c|c|c|c|c|}
\hline \multirow[t]{2}{*}{ Patient } & \multirow[t]{2}{*}{ Gender } & \multirow[t]{2}{*}{ Age } & \multirow[t]{2}{*}{ Total cell dose } & \multirow[t]{2}{*}{ Injection Route } & \multirow{2}{*}{$\begin{array}{l}\text { Follow-up } \\
\text { (months) }\end{array}$} & \multicolumn{2}{|c|}{ Extent } & \multicolumn{2}{|c|}{ Intensity } & \multicolumn{2}{|c|}{ Pruritus/Insomnia } & \multicolumn{2}{|c|}{ Total score } \\
\hline & & & & & & Pre & Post & Pre & Post & Pre & Post & Pre & Post \\
\hline 1 & $\mathrm{~F}$ & $27 y$ & $6 \times 10^{8}$ & Intravenous & $51 / 2$ & 98 & 98 & 17 & 11 & 14 & 3 & 93.1 & 61.1 \\
\hline 2 & $M$ & $33 y$ & $6 \times 10^{8}$ & Intravenous & $41 / 2$ & 75 & 75 & 7 & 5 & 14 & 3 & 57 & 35.5 \\
\hline 3 & $\mathrm{~F}$ & $27 y$ & $1 \times 10^{9}$ & Intravenous & $31 / 2$ & 12 & 7 & 8 & 4 & 3 & 1 & 33.4 & 16.4 \\
\hline 4 & $\mathrm{~F}$ & $26 y$ & $6 \times 10^{8}$ & Intravenous & 2 & 18 & 4 & 7 & 3 & 11 & 2 & 39.1 & 13.3 \\
\hline
\end{tabular}

SCORing Atopic Dermatitis (SCORAD) index in atopic dermatitis patients before and after the stem cells treatment (see also Additional File 1, Case Reports).

\section{Conclusions}

Human AdMSC can be isolated from small amounts of adipose tissue, efficiently expanded to achieve more than $10^{9}$ cells after 3 to 4 passages independent on donor age and disease status. The sustained potency and genetic stability of the cells make adipose tissue a very attractive source for multipotent cells. Their immunmodulatory function, homing and migratory patterns as well as previous clinical trials suggest that these cells are efficient for treatment for several classes of autoimmune diseases and their application is safe. Here, we demonstrated considerable therapeutic effects of cultureexpanded autologous AdMSCs in a variety of autoimmune diseases in the frame of an ethically justified compassionate use application for patients with exhausted therapeutic options. Multiple intravenous infusions of cells resulted in clinical benefit in all treated patients in the follow up period. No adverse events were observed. The data provide first evidence for clinical benefit in autoimmune diseases, yet further scrutiny in controlled clinical trials with a sufficient numbers of patients are needed to draw a definitive conclusion on therapeutic efficacy and long term benefit. Importantly, the data show that multiple AdMSC infusion of up to $1 \times 10^{9}$ cells in a period of less than one month is safe, corroborating data from preclinical and clinical trials using BMMSC and AdMSC. Furthermore, within this small sample size, no evidence of donor age-dependent efficacy, or age dependent in vitro cell expansion rate was found. The autologous stem cell application described here is based on the current state of the art and provides an outlook into treatments for patients suffering from a variety of incurable autoimmune related diseases with no remaining treatment options. While it is shown here that the technology for treatment of autoimmune using autologous AdMSC is in place and the expectations derived from preclinical studies can be confirmed, there is still a limited understanding of the modes of action. In conclusion, the systemic infusion of autologous stem cells described here offers promise for better management of a wide spectrum of autoimmune diseases, independent on patient's age.

\section{Additional material}

Additional file 1: Individual case reports, Table S1, and Figure S1 The file contains detailed clinical case reports for each of the treated patients with autoimmune hearing loss (AIED), multiple sclerosis (MS), polymyotitis (PM), atopic dermatitis (AD) and rheumatoid arthritis (RA). Table S1 shows the manual muscle test (MMT) grading, grading scheme for manual muscle test (MMT) in patients with MS and PM. Figure S1 shows the audiograms and conduction test for patient with AIED. Audiograms are shown for left and right ears before and after AdMSC treatment.

\section{Acknowledgements}

We thank M.S. Ko, J.H. Kang, S.J. Lee, W.J. Kim for collecting data and stimulating discussions.

\section{Author details}

${ }^{1}$ Stem Cell Research Center, RNL BIO, Seoul, 153-768, Republic of Korea. ${ }^{2}$ Otorhinolaryngology, Bethesda Samsung Hospital, Yangsan, GyeongNam Province, 626-701, Korea. ${ }^{3}$ Graduate School of Immunology, College of 
Medicine, Seoul National University and Department of Experimental Animal Research, Biomedical Research Institute, Seoul National University Hospital, 101 Daehang-ro, Jongno-gu, Seoul 110-744, Republic of Korea. ${ }^{4}$ Semyung University, 579 Sinwoul-dong, Jecheon City, Chungbuk, 390-711, Republic of Korea. ${ }^{5}$ Kyoto Bethesda Clinic, Minami-ku, Kyoto, 601-8475, Japan. ${ }^{6}$ Yanji Chaoyang Zaisheng Hospital, Limin Street, Chaoyangchuan Town, Yanji City, Jilin Province, China. 'St. Mary Medical Center, OB Clinic, Long Beach, 90813, CA, USA. ${ }^{8}$ Berlin-Brandenburg Center for Regenerative Therapies, Augustenburger Platz 1, 13353 Berlin, Germany and Seoul National University, College of Veterinary Medicine, Seoul, Korea.

\section{Authors' contributions}

JCR: involved in the preparation and in vitro and in vivo characterization of AdMSCs and designed the protocol of stem cell treatment and managed the clinical cases along with clinicians. SAJ: designed the protocol of stem cell treatment and cared the patients. NK: cared and treated autoimmune patients. MP: cared and treated autoimmune patients. BS: cared autoimmune inner ear disease patient and evaluated the data. SKK: performed the migration and homing potential of AdMSCs and drafted and revised the manuscript. ISS: designed and performed characterization of AdMSCs including distribution, immunophenotyping and in vitro differentiation of AdMSCs. HGP: cultured AdMSCs and performed in vitro safety and stability test of AdMSCs. JGK: analyzed and evaluated the data of autoimmune inner ear disease. BKK: performed the experiments of in vivo safety of AdMSCs. YSL: designed and evaluated data of safety and distribution of AdMSCS. AK drafted and revised the manuscript, organized and evaluated data. All authors read and approved the final manuscript

\section{Competing interest Statement}

Jeong Geun Kim, Byeong Chul Kang, Yong Soon Lee, Ken Nakama, Min Piao, Betram Sohl and Andras Kurtz have no competing financial or personal interests in this work. Jeong Chan Ra, Sung Keun Kang, II Sub Shin and Hyeong Geun Park are employees and shareholders of RNL BIO Limited, which holds patents on some of the technologies in this manuscript. San Aun Joo is employee of RNL BIO and declares no competing financial interests.

Received: 22 September 2011 Accepted: 21 October 2011

Published: 21 October 2011

\section{References}

1. Si YL, Zhao YL, Hao HJ, Fu XB, Han WD: MSC: Biological characteristics, clinical applications and their outstanding concerns. Ageing Res Rev 2011, 10:93-103.

2. Parekkadan B, Milwid JM: Mesenchymal stem cells as therapeutics. Annu Rev Biomed Eng 2010, 12:87-117.

3. García-Gómez I, Elvira G, Zapata AG, Lamana ML, Ramírez M, Castro JG, Arranz MG, Vicente A, Bueren J, García-Olmo D: Mesenchymal stem cells: biological properties and clinical applications. Expert Opin Biol Ther 2010 10:1453-1468

4. Ra JC, Shin IS, Kim SH, Kang SK, Kang BC, Lee HY, Kim YJ, Jo JY, Yoon EJ, Choi HJ, Kwon E: Safety of intravenous infusion of human adipose tissuederived mesenchymal stem cells in animals and humans. Stem Cells Dev 2011, 20(8):1295-6

5. Jo JY, Kang SK, Choi IS, Ra JC: Comparison of neural cell differentiation of human adipose mesenchymal stem cells derived from young and old ages. Devel Reprod 2009, 13:227-237.

6. Pittenger MF, Mackay AM, Beck SC, Jaiswal RK, Douglas R, Mosca JD, Moorman MA, Simonetti DW, Craig S, Marshak DR: Multilineage potential of adult human mesenchymal stem cells. Science 1999, 284:143-147.

7. Jiang $Y$, Jahagirdar BN, Reinhardt RL, Schwartz RE, Keene CD, OrtizGonzalez XR, Reyes M, Lenvik T, Lund T, Blackstad M, Du J, Aldrich S, Lisberg A, Low WC, Largaespada DA, Verfaillie CM: Pluripotency of mesenchymal stem cells derived from adult marrow. Nature 2002 418:41-49.

8. Lee OK, Kuo TK, Chen WM, Lee KD, Hsieh SL, Chen TH: Isolation of multipotent mesenchymal stem cells from umbilical cord blood. Blood 2004, 103:1669-1675

9. Nauta AJ, Fibbe WE: Immunomodulatory properties of mesenchyma stromal cells. Blood 2007, 110:3499-3506.
10. Oh JY, Kim MK, Shin MS, Lee HJ, Ko JH, Wee WR, Lee JH: The antiinflammatory and antiangiogenic role of mesenchymal stem cells in corneal wound healing following chemical injury. Stem Cells 2008, 26:1047-1055.

11. Ankrum J, Karp JM: Mesenchymal stem cell therapy: two steps forward, one step back. Trends Mol Med 2010, 16:203-209.

12. Choi YH, Kurtz A, Stamm C: Mesenchymal stem cells for cardiac cell therapy. Hum Gene Ther 2011, 22:3-17.

13. Zhang M, Mal N, Kiedrowski M, Chacko M, Askari AT, Popovic ZB, Koc ON, Penn MS: SDF-1 expression by mesenchymal stem cells results in trophic support of cardiac myocytes after myocardial infarction. FASEB J 2007 , 21:3197-3207.

14. Togel F, Weiss K, Yang Y, Hu Z, Zhang P, Westenfelder C: Vasculotropic, paracrine actions of infused mesenchymal stem cells are important to the recovery from acute kidney injury. Am J Physiol Renal Physiol 2007, 292:F1626-F1635.

15. Yañez R, Lamana ML, García-Castro J, Colmenero I, Ramírez M, Bueren JA: Adipose tissue-derived mesenchymal stem cells have in vivo immunosuppressive properties applicable for the control of the graftversus-host disease. Stem Cells 2006, 24:2582-2591.

16. Zappia E, Casazza S, Pedemonte E, Benvenuto F, Bonanni I, Gerdoni E, Giunti D, Ceravolo A, Cazzanti F, Frassoni F, Mancardi G, Uccelli A: Mesenchymal stem cells ameliorate experimental autoimmune encephalomyelitis inducing T-cell anergy. Blood 2005, 106:1755-1761.

17. Djouad F, Bouffi C, Ghannam S, Noël D, Jorgensen C: Mesenchymal stem cells: innovative therapeutic tools for rheumatic diseases. Nat Rev Rheumatol 2009, 5:392-399.

18. Augello A, Tasso R, Negrini SM, Cancedda R, Pennesi G: Cell therapy using allogeneic bone marrow mesenchymal stem cells prevents tissue damage in collagen-induced arthritis. Arthritis Rheum 2007, 56:1175-1186.

19. Cai L, Johnstone BH, Cook TG, Tan J, Fishbein MC, Chen PS, March KL: IFATS collection: Human adipose tissue-derived stem cells induce angiogenesis and nerve sprouting following myocardial infarction, in conjunction with potent preservation of cardiac function. Stem Cells 2009, 27:230-237

20. Choi EW, Shin IS, Lee HW, Park SY, Park JH, Nam MH, Kim JS, Woo SK, Yoon EJ, Kang SK, Ra JC, Youn HY, Hong SH: Transplantation of CTLA4lg gene-transduced adipose tissue-derived mesenchymal stem cells reduces inflammatory immune response and improves Th1/Th2 balance in experimental autoimmune thyroiditis. J Gene Med 2011, 13:3-16.

21. Phinney DG, Prockop DJ: Concise review: mesenchymal stem/multipotent stromal cells: the state of transdifferentiation and modes of tissue repair-current views. Stem Cells 2007, 25:2896-2902.

22. Song H, Song BW, Cha MJ, Choi IG, Hwang KC: Modification of mesenchymal stem cells for cardiac regeneration. Expert Opin Biol Ther 2010, 10:309-319

23. Mizuno H: Adipose-derived stem cells for tissue repair and regeneration: ten years of research and a literature review. J Nippon Med Sch 2009, 76:56-66.

24. Banas A, Teratani T, Yamamoto Y, Tokuhara M, Takeshita F, Osaki M, Kawamata M, Kato T, Okochi H, Ochiya T: IFATS collection: in vivo therapeutic potential of human adipose tissue mesenchymal stem cells after transplantation into mice with liver injury. Stem Cells 2008 26:2705-2712.

25. Lu D, Li Y, Wang L, Chen J, Mahmood A, Chopp M: Intraarterial administration of marrow stromal cells in a rat model of traumatic brain injury. J Neurotrauma 2001, 18:813-819.

26. Chen J, Li Y, Chopp M: Intracerebral transplantation of bone marrow with BDNF after MCAo in rat. Neuropharmacology 2000, 39:711-716.

27. Detante O, Moisan A, Dimastromatteo J, Richard MJ, Riou L, Grillon E, Barbier E, Desruet MD, De Fraipont F, Segebarth C, Jaillard A, Hommel M, Ghezzi C, Remy C: Intravenous administration of 99mTc-HMPAO-labeled human mesenchymal stem cells after stroke: in vivo imaging and biodistribution. Cell Transplant 2009, 18:1369-1379.

28. Lee RH, Pulin AA, Seo MJ, Kota DJ, Ylostalo J, Larson BL, Semprun-Prieto L, Delafontaine P, Prockop DJ: Intravenous hMSCs improve myocardial infarction in mice because cells embolized in lung are activated to secrete the anti-inflammatory protein TSG-6. Cell Stem Cell 2009, 5:54-63.

29. Mosna F, Sensebe L, Krampera M: Human bone marrow and adipose tissue mesenchymal stem cells: a user's guide. Stem Cells 2010, 19:1449-1470 
30. Dominici M, Le Blanc K, Mueller I, Slaper-Cortenbach I, Marini F, Krause D, Deans R, Keating A, Prockop D, Horwitz E: Minimal criteria for defining multipotent mesenchymal stromal cells. The International Society for Cellular Therapy position statement. Cytotherapy 2006, 8:315-317.

31. Tomita Y, Makino S, Hakuno D, Hattan N, Kimura K, Miyoshi S, Murata M, leda M, Fukuda K: Application of mesenchymal stem cell derived cardiomyocytes as bio-pacemakers: current status and problems to be solved. Med Biol Eng Comput 2007, 45:209-220.

32. Gojo S, Gojo N, Takeda Y, Mori T, Abe H, Kyo S, Hata J, Umezawa A: In vivo cardiovasculogenesis by direct injection of isolated adult mesenchymal stem cells. Exp Cell Res 2003, 288:51-59.

33. Barbash IM, Chouraqui P, Baron J, Feinberg MS, Etzion S, Tessone A, Miller J, Guetta E, Zipori D, Kedes LH, Kloner RA, Leor J: Systemic delivery of bone marrow-derived mesenchymal stem cells to the infarcted myocardium: feasibility, cell migration, and body distribution. Circulation 2003, 108:863-868.

34. Psaltis PJ, Zannettino AC, Worthley SG, Gronthos S: Concise review: mesenchymal stromal cells: potential for cardiovascular repair. Stem Cells 2008, 26:2201-2210.

35. Friedenstein AJ, Petrakova KV, Kurolesova Al, Frolova GP: Heterotopic of bone marrow. Analysis of precursor cells for osteogenic and hematopoietic tissues. Transplantation 1968, 6:230-247.

36. Bianco P, Robey PG, Simmons PJ: Mesenchymal stem cells: revisiting history, concepts, and assays. Cell Stem Cell 2008, 2:313-319.

37. Rebelatto CK, Aguiar AM, Moretao MP, Senegaglia AC, Hansen P, Barchiki F, Oliveira J, Martins J, Kuligovski C, Mansur F, Christofis A, Amaral VF, Brofman PS, Goldenberg S, Nakao LS, Correa A: Dissimilar differentiation of mesenchymal stem cells from bone marrow, umbilical cord blood, and adipose tissue. Exp Biol Med 2008, 233:901-913.

38. Alviano F, Fossati V, Marchionni C, Arpinati M, Bonsi L, Franchina M, Lanzoni G, Cantoni S, Cavallini C, Bianchi F, Tazzari PL, Pasquinelli G, Foroni L, Ventura C, Grossi A, Bagnara GP: Term Amniotic membrane is a high throughput source for multipotent mesenchymal stem cells with the ability to differentiate into endothelial cells in vitro. BMC Dev Biol 2007, 7:11

39. D'Ippolito G, Diabira S, Howard GA, Menei P, Roos BA, Schiller PC: Marrowisolated adult multilineage inducible (MIAMI) cells, a unique population of postnatal young and old human cells with extensive expansion and differentiation potential. J Cell Sci 2004, 117:2971-2981.

40. Kassem M, Kristiansen M, Abdallah BM: Mesenchymal stem cells: cell biology and potential use in therapy. Basic Clin Pharmacol Toxicol 2004, 95:209-214.

41. Gronthos S, Zannettino AC, Hay SJ, Shi S, Graves SE, Kortesidis A, Simmons PJ: Molecular and cellular characterisation of highly purified stromal stem cells derived from human bone marrow. J Cell Sci 2003 , 116:1827-1835.

42. Stenderup $\mathrm{K}$, Justuesen J, Clausen C, Kassem M: Aging is associated with decreased maximal life span and accelerated senescence of bone marrow stromal cells. Bone 2003, 6:919-926.

43. Zuk PA, Zhu M, Ashiian P, De Ugarte DA, Huang Jl, Mizuno H, Alfonso ZC, Fraser JK, Benhaim P, Hedrick MH: Human adipose tissue is a source of multipotent stem cells. Mol Biol Cell 2002, 13:4279-4295.

44. Sen A, Lea-Currie YR, Sujkowska D, Franklin DM, Wilkison WO, Halvorsen YD, Gimble JM: Adipogenic potential of human adipose derived stromal cells from multiple donors is heterogeneous. J Cell Biochem 2001, 81:312-319.

45. Mizuno H: Adipose-derived stem and stromal cells for cell-based therapy: current status of preclinical studies and clinical trials. Curr Opin Mol Ther 2010, 12:442-449.

46. Wei X, Du Z, Zhao L, Feng D, Wei G, He Y, Tan J, Lee WH, Hampel H, Dodel R, Johnstone BH, March ML, Farlow MR, Du Y: IFATS collection: The conditioned media of adipose stromal cells protect against hypoxiaischemia-induced brain damage in neonatal rats. Stem Cells 2009, 27:478-488.

47. Cho KS, Park HK, Park HY, Jung JS, Jeon SG, Kim YK, Roh HJ: IFATS collection: Immunomodulatory effects of adipose tissue-derived stem cells in an allergic rhinitis mouse model. Stem Cells 2009, 27:259-265.

48. Bacou F, el Andalousi RB, Daussin PA, Micallef JP, Levin JM, Chammas M, Casteilla L, Reyne Y, Nougues J: Transplantation of adipose tissue-derived stromal cells increases mass and functional capacity of damaged skeletal muscle. Cell Transplant 2004, 13:103-111.
49. Wislet-Gendebien S, Leprince P, Moonen G, Rogister B: Regulation of neural markers nestin and GFAP expression by cultivated bone marrow stromal cells. J Cell Sci 2003, 116:3295-3302.

50. Bonab MM, Alimoghaddam K, Talebian F, Ghaffari SH, Ghavamzadeh A, Nikbin B: Aging of mesenchymal stem cell in vitro. BMC Cell Biol 2006, 10:7-14.

51. Wagner W, Horn P, Castoldi M, Diehlmann A, Bork S, Saffrich R, Benes V, Blake J, Pfister S, Eckstein V, Ho AD: Replicative senescence of mesenchymal stem cells: a continuous and organized process. PLoS One 2008, 3:e2213.

52. Wagner W, Ho AD, Zenke M: Different facets of aging in human mesenchymal stem cells. Tissue Eng Part B Rev 2010, 16:445-453.

53. Briquet A, Dubois S, Bekaert S, Dolhet M, Beguin Y, Gothot A: Prolonged ex vivo culture of human bone marrow mesenchymal stem cells influences their supportive activity toward NOD/SCID-repopulating cells and committed progenitor cells of B lymphoid and myeloid lineages. Haematologica 2010, 95:47-56.

54. Lazarus HM, Haynesworth SE, Gerson SL, Rosenthal NS, Caplan Al: Ex vivo expansion and subsequent infusion of human bone marrow-derived stromal progenitor cells (mesenchymal progenitor cells): implications for therapeutic use. Bone Marrow Transplant 1995, 16:557-564.

55. Horwitz EM, Gordon PL, Koo WKK, Marx JC, Neel MD, MCNall RY, Muul L, Hofmann T: Isolated allogeneic bone marrow-derived mesenchymal cells engraft and stimulate growth in children with osteogenesis imperfecta: Implications for cell therapy of bone. Proc Natl Acad Sci 2002, 99:8932-8937.

56. Koç ON, Day J, Nieder M, Gerson SL, Lazarus HM, Krivit W: Allogeneic mesenchymal stem cell infusion for treatment of metachromatic leukodystrophy (MLD) and Hurler syndrome (MPS-IH). Bone Marrow Transplant 2002, 30:215-222.

57. Chen S, Fang W, Ye F, Liu Y, Qian J, Shan S, Zhang J, Chunhua RZ, Liao L, Lin S, Sun J: Effect on left ventricular function of intracoronary transplantation of autologous bone marrow mesenchymal stem cell in patients with acute myocardial infarction. The Am J Cardiol 2004, 94:92-95.

58. Le Blanc K, Frassoni F, Ball L, Locatelli F, Roelofs H, Lewis I, Lanino E, Sundberg B, Bernardo ME, Remberger M, Dini G, Egeler RM, Bacigalupo A, Fibbe W, Ringdén O: Mesenchymal stem cells for treatment of steroidresistant, severe, acute graft-versus-host disease: a phase II study. Lancet 2008, 371:1579-1586.

59. Tolar J, Nauta AJ, Osborn MJ, Panoskaltsis Mortari A, McElmurry RT, Bell S, Xia L, Zhou N, Riddle M, Schroeder TM, Westendorf JJ, Mclvor RS, Hogendoorn PCW, Szuhai K, Oseth L, Hirsch B, Yant SR, Kay MA, Peister A, Prockop DJ, Fibbe WE, Blazar BR: Sarcoma derived from cultured mesenchymal stem cells. Stem Cells 2007, 25:371-379.

60. Zimmerlin L, Donnenberg AD, Rubin JP, Landreneau RJ, Basse P, Donnenberg VS: Regenerative therapy and cancer: In vitro and in vivo studies of the interaction between adipose-derived stem cells and breast cancer cells from clinical isolates. Tissue Eng 2011, 17:93-106.

61. Vilalta M, Dégano IR, Bagó J, Gould D, Santos M, García-Arranz M, Ayats R, Fuster C, Chernajovsky Y, García-Olmo D, Rubio N, Blanco J: Biodistribution, long-term survival, and safety of human adipose tissue-derived mesenchymal stem cells transplanted in nude mice by high sensitivity non-invasive bioluminescence imaging. Stem Cells Dev 2008, 17:993-1003.

62. Izadpanah R, Kaushal D, Kriedt C, Tsien F, Patel B, Dufour J, Bunnell BA: Long-term in vitro expansion alters the biology of adult mesenchymal stem cells. Cancer Res 2008, 68:4229-4238.

63. Mendes SC, Tibbe JM, Veenhof M, Bakker K, Both S, Platenburg PP, Oner FC, de Bruijn JD, van Blitterswijk CA: Bone tissue-engineered implants using human bone marrow stromal cells: Effect of culture conditions and donor age. Tissue Eng 2002, 8:911-920.

64. Huibregtse BA, Johnstone B, Goldberg VM, Caplan Al: Effect of age and sampling site on the chondro-osteogenic potential of rabbit marrowderived mesenchymal progenitor cells. J Orthop Res 2000, 18:18-24.

65. Bergman RJ, Gazit D, Kahn AJ, Gruber H, McDougall S, Hahn TJ: Age-related changes in osteogenic stem cells in mice. J Bone Miner Res 1996, 11:568-577.

66. Chen HT, Lee MJ, Chen CH, Chuang SC, Chang LF, Ho ML, Hung SH, Fu YC, Wang $\mathrm{YH}$, Wang HI, Wang GJ, Kang L, Chang JK: Proliferation and differentiation potential of human adipose-derived mesenchymal stem 
cells isolated from elderly patients with osteoporotic fractures. J Cell Mol Med 2011.

67. Mirsaidi A, Kleinhans KN, Rimann M, Tiaden AN, Stauber M, Rudolph KL, Richards PJ: Telomere length, telomerase activity and osteogenic differentiation are maintained in adipose-derived stromal cells from senile osteoporotic SAMP6 mice. J Tissue Eng Regen Med 2011.

68. Gao J, Dennis JE, Muzic RF, Lundberg M, Caplan Al: The dynamic in vivo distribution of bone marrow derived mesenchymal stem cells after infusion. Cells Tiss Organs 2001, 169:12-20.

69. Devine SM, Cobbs C, Jennings M, Bartholomew A, Hoffman R: Mesenchymal stem cells distribute to a wide range of tissues following systemic infusion into nonhuman primates. Blood 2003, 101:2999-3001.

70. Bensidhoum M, Chapel A, Francois S, Demarquay C, Mazurier C, Fouillard L, Bouchet S, Bertho JM, Gourmelon P, Aigueperse J, Charbord P, Gorin NC, Thierry D, Lopez M: Homing of in vitro expanded Stro-1- or Stro-1+ human mesenchymal stem cells into the NOD/SCID mouse and their role in supporting human CD34 cell engraftment. Blood 2004, 103:3313-3319

71. Deak E, Seifried E, Henschler R: Homing pathways of mesenchymal stromal cells (MSCs) and their role in clinical applications. Int Rev Immunol 2010, 295:514-529.

72. Deak E, Rúster B, Keller L, Eckert K, Fichtner I, Seifried E, Henschler R: Suspension medium influences interaction of mesenchymal stromal cells with endothelium and pulmonary toxicity after transplantation in mice. Cytotherapy 2010, 12:260-264.

73. Chapel A, Bertho JM, Bensiodhoum M, Fouillard L, Young RG, Frick J, Demarquay C, Cuvelier F, Mathieu E, Trompier F, Dudoignon N, Germain C, Mazurier C, Aigueperse J, Borneman J, Gorin NC, Goumelon P, Thierry D: Mesenchymal stem cells home to injured tissues when co-infused with hematopoietic cells to treat a radiation-induced multi organ failure syndrome. J Gene Med 2003, 5:1028-1038.

74. Chavakis E, Urbich C, Dimmeler S: Homing and engraftment of progenitor cells: a prerequisite for cell therapy. J Mol Cell Cardiol 2008, 45:514-522.

75. Saito T, Kuang J, Bittira B, Al-Khaldi A, Chiu RCJ: Xenotransplant cardiac chimera: immune tolerance of adult stem cells. Ann Thorac Surg 2002, 74:19-24.

76. Mouiseddine M, François S, Semont A, Sache A, Allenet B, Mathieu N, Frick J, Thierry D, Chapel A: Human mesenchymal stem cells home specifically to radiation-injured tissues in a non-obese diabetes/severe combined immunodeficiency mouse model. Br J Radiol 2007, 80:549-55.

77. Sordi V, Malosio ML, Marchesi F, Mercalli A, Melzi R, Giordano T, Belmonte N, Ferrari G, Leone BE, Bertuzzi F, Zerbini G, Allavena P. Bonifacio $E$, Piemonti L: Bone marrow mesenchymal stem cells express a restricted set of functionally active chemokine receptors capable of promoting migration to pancreatic islets. Blood 2005, 106:419-427.

78. Baek SJ, Kang SK, Ra JC: In vitro migration capacity of human adiposederived mesenchymal stem cells and their expression of a distinct set of chemokine and growth factor receptors. Exp Mol Med 2011

79. Le Blanc K, Ringden O: Immunomodulation by mesenchymal stem cells and clinical experience. J Intern Med 2007, 262:509-525.

80. Djouad F, Charbonnier LM, Bouffi C, Louis-Plence P, Bony C, Apparailly F, Cantos C, Jorgensen C, Noel D: Mesenchymal stem cells inhibit the differentiation of dendritic cells through an interleukin-6-dependent mechanism. Stem Cells 2007, 25:2025-2032.

81. Meirelles Lda S, Fontes AM, Covas DT, Caplan Al: Mechanisms involved in the therapeutic properties of mesenchymal stem cells. Cytokine Growth Factor Rev 2009, 20:419-427.

82. Rasmusson I, Ringdén O, Sundberg B, Le Blanc K: Mesenchymal stem cells inhibit lymphocyte proliferation by mitogens and alloantigens by different mechanisms. Exp Cell Res 2005, 305:33-41.

83. Corcione A, Benvenuto F, Ferretti E, Giunti D, Cappiello V, Cazzanti F, Risso M, Gualandi F, Mancardi GL, Pistoia V, Uccelli A: Human mesenchymal stem cells modulate B-cell functions. Blood 2006, 107:367-372

84. Spaggiari GM, Capobianco A, Abdelrazik H, Becchetti F, Mingari MC Moretta L: Mesenchymal stem cells inhibit natural killer-cell proliferation, cytotoxicity, and cytokine production: role of indoleamine 2, 3dioxygenase and prostaglandin E2. Blood 2008, 111:1327-1333

85. Jiang XX, Zhang Y, Liu B, Zhang SX, Wu Y, Yu XD, Mao N: Human mesenchymal stem cells inhibit differentiation and function of monocyte-derived dendritic cells. Blood 2005, 105:4120-4126.
86. Ren G, Zhang L, Zhao X, Xu G, Zhang Y, Roberts Al, Zhao RC, Shi Y: Mesenchymal stem cell-mediated immunosuppression occurs via concerted action of chemokines and nitric oxide. Cell Stem Cell 2008, 2:141-150.

87. Krampera M, Glennie S, Dyson J, Scott D, Laylor R, Simpson E, Dazzi F: Bone marrow mesenchymal stem cells inhibit the response of naive and memory antigen-specific T cells to their cognate peptide. Blood 2003, 101:3722-3729.

88. Al-Refu K, Goodfield M: Hair follicle stem cells in the pathogenesis of the scarring process in cutaneous lupus erythematosus. Autoimmun Rev 2009, 8:474-477.

89. Papadaki HA, Kritikos HD, Gemetzi C, Koutala H, Marsh JC, Boumpas DT Eliopoulos GD: Bone marrow progenitor cell reserve and function and stromal cell function are defective in rheumatoid arthritis: evidence for a tumor necrosis factor alphamediated effect. Blood 2002, 99:1610-1619.

90. Papadaki HA, Tsagournisakis M, Mastorodemos V, Pontikoglou C, Damianaki A, Pyrovolaki K, Stamatopoulos K, Fassas A, Plaitakis A, Eliopoulos GD: Normal bone marrow hematopoietic stem cell reserves and normal stromal cell function support the use of autologous stem cell transplantation in patients with multiple sclerosis. Bone Marrow Transplant 2005, 36:1053-1063.

91. Bocelli-Tyndall C, Bracci L, Spagnoli G, Braccini A, Bouchenaki M, Ceredig R, Pistoia V, Martin I, Tyndall A: Bone marrow mesenchymal stromal cells (BM-MSCs) from healthy donors and auto-immune disease patients reduce the proliferation of autologous- and allogeneic-stimulated lymphocytes in vitro. Rheumatology 2007, 46:403-408.

92. Mazzanti B, Aldinucci A, Biagioli T, Barilaro A, Urbani S, Dal PS, Amato MP, Siracusa G, Crescioli C, Manuelli C, Bosi A, Saccardi R, Massacesi L, Ballerini C: Differences in mesenchymal stem cell cytokine profiles between MS patients and healthy donors: implication for assessment of disease activity and treatment. J Neuroimmunol 2008, 199:142-150.

93. McCabe BF: Autoimmune sensorineural hearing loss. Ann Otol Rhinol Laryngol 1979, 88:585-589.

94. Buniel MC, Geelan-Hansen K, Weber PC, Tuohy VK: Immunosuppressive therapy for autoimmune inner ear disease. Immunotherapy 2009, 1:425-434

95. Baek MJ, Park HM, Johnson JM, Altuntas CZ, Jane-Wit D, Jaini R, Solares CA, Thomas DM, Ball EJ, Robertson NG, Morton CC, Hughes GB, Tuohy VK: Increased frequencies of cochlin-specific T cells in patients with autoimmune sensorineural hearing loss. J Immunol 2006, 177:4203-4210.

96. Bovo R, Aimoni C, Martini A: Immune-mediated inner ear disease. Acta Otolaryngol 2006, 126:1012-1021.

97. Agrup C: Immune-mediated audiovestibular disorders in the paediatric population: a review. Int J Audiol 2008, 47:560-565.

98. Zhou Y, Yuan J, Zhou B, Lee AJ, Lee AJ, Ghawji M Jr, Yoo TJ: The therapeutic efficacy of human adipose tissue-derived mesenchymal stem cells on experimental autoimmune hearing loss in mice. Immunology 2011, 133:133-140.

99. Muraro PA, Martin R: Immunological questions on hematopoietic stem cell transplantation for multiple sclerosis. Bone Marrow Transplant 2003, 32(Suppl 1):S41-44.

100. Vosoughi R, Freedman MS: Therapy of MS. Clin Neurol Neurosurg 2010, 112:365-385.

101. Constantin G, Marconi S, Rossi B, Angiari S, Calderan L, Anghileri E, Gini B, Bach SD, Martinello M, Bifari F, Galiè M, Turano E, Budui S, Sbarbati A, Krampera M, Bonetti B: Adipose-derived mesenchymal stem cells ameliorate chronic experimental autoimmune encephalomyelitis. Stem Cells 2009, 27:2624-2635.

102. Riordan NH, Ichim TE, Min WP, Wang H, Solano F, Lara F, Alfaro M, Rodriguez JP, Harman RJ, Patel AN, Murphy MP, Lee RR, Minev B: Nonexpanded adipose stromal vascular fraction cell therapy for multiple sclerosis. J Transl Med 2009, 7:29.

103. Yamout B, Hourani R, Salti H, Barada W, El-Haij T, Al-Kutoubi A, Herlopian A, Baz EK, Mahfouz R, Khalil-Hamdan R, Kreidieh NM, El-Sabban M, Bazarbachi A: Bone marrow mesenchymal stem cell transplantation in patients with multiple sclerosis: a pilot study. J Neuroimmunol 2010, 227:185-189.

104. Ko MS, Park HG, Yun YM, Ra JC, Shin T, Lee KK: Ameliorative effects of human adipose tissue-derived mesenchymal stem cells on myelin basic protein-induced experimental autoimmune encephalomyelitis in Lewis rats. Neural Regeneration Research 2011. 
105. Dalakas MC: Immunotherapy of myositis: issues, concerns and future prospects. Nat Rev Rheumatol 2010, 6:129-137.

106. Henes JC, Heinzelmann F, Wacker A, Seelig HP, Klein R, Bornemann A, Faul C, Kanz L, Koetter l: Antisignal recognition particle-positive polymyositis successfully treated with myeloablative autologous stem cell transplantation. Ann Rheum Dis 2009, 68:447-448.

107. Wang D, Zhang H, Cao M, Tang Y, Liang J, Feng X, Wang H, Hua B, Liu B, Sun L: Efficacy of allogeneic mesenchymal stem cell transplantation in patients with drug-resistant polymyositis and dermatomyositis. Ann Rheum Dis 2011, 70:1285-1288.

108. Saeki HM, Furue, Furukawa F, Hide M, Ohtsuki M, Katayama I, Sasaki R, Suto H, Takehara K: Guidelines for management of atopic dermatitis. $J$ Dermatol 2009, 36:563-577.

109. Galli E, Cicconi R, Rossi P, Casati A, Brunetti E, Mancino G: Atopic dermatitis: molecular mechanisms, clinical aspects and new therapeutical approaches. Curr Mol Med 2003, 3:127-138.

110. Ellis C, Luger T, Abeck D, Allen R, Graham-Brown RAC, De Prost $Y$, Eichenfield LF, Ferrandiz C, Giannetti A, Hanifin J, Koo JYM, Leung D, Lynde C, Ring J, Ruiz-Maldonado R, Saurat J-H: International Consensus Conference on Atopic Dermatitis II (ICCAD II): clinical update and current treatment strategies. Br J Dermatol 2003, 148(Suppl):3-10, 63.

111. Charman CR, Morris AD, Williams HC: Topical corticosteroid phobia in patients with atopic eczema. Br J Dermatol 2000, 142:931-936.

112. Gonzalez-Rey E, Gonzalez MA, Varela N, O'Valle F, Hernandez-Cortes P, Rico L, Büscher D, Delgado M: Human adipose-derived mesenchymal stem cells reduce inflammatory and $T$ cell responses and induce regulatory T cells in vitro in rheumatoid arthritis. Ann Rheum Dis 2010 69:241-248.

113. González MA, Gonzalez-Rey E, Rico L, Büscher D, Delgado M: Treatment of experimental arthritis by inducing immune tolerance with human adipose-derived mesenchymal stem cells. Arthritis Rheum 2009, 60:1006-1019.

114. Liu Y, Mu R, Wang S, Long L, Liu X, Li R, Sun J, Guo J, Zhang X, Guo J, Yu P, Li C, Liu X, Huang Z, Wang D, Li H, Gu Z, Liu B, Li Z: Therapeutic potential of human umbilical cord mesenchymal stem cells in the treatment of rheumatoid arthritis. Arthritis Res Ther 2010, 12:R210.

115. Angelova-Fischer I, Bauer A, Hipler UC, Petrov I, Kazandjieva J, Bruckner T, Diepgen T, Tsankov N, Williams M, Fischer TW, Elsner P, Fluhr JW: The objective severity assessment of atopic dermatitis (OSAAD) score: validity, reliability and sensitivity in adult patients with atopic dermatitis. Br J Dermatol 2005, 153:767-773.

116. No authors listed: Severity scoring of atopic dermatitis: the SCORAD index. Consensus report of the European Task Force on atopic dermatitis. Dermatology 1993, 186:23-31.

doi:10.1186/1479-5876-9-181

Cite this article as: Ra et al.: Stem cell treatment for patients with autoimmune disease by systemic infusion of culture-expanded autologous adipose tissue derived mesenchymal stem cells. Journal of Translational Medicine 2011 9:181.

\section{Submit your next manuscript to BioMed Central and take full advantage of:}

- Convenient online submission

- Thorough peer review

- No space constraints or color figure charges

- Immediate publication on acceptance

- Inclusion in PubMed, CAS, Scopus and Google Scholar

- Research which is freely available for redistribution

Submit your manuscript at www.biomedcentral.com/submit
Biomed Central 